\title{
Development and Validation of the Online Histrionic Personality Scale (OHPS) Using the DSM-5 Criteria for Histrionic Personality Disorder
}

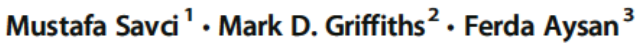 \\ Received: 4 November 2019 / Revised: 18 March 2020 /Accepted: 2 May 2020 \\ (C) Springer Nature Switzerland AG 2020
}

\begin{abstract}
The present study evaluated personality presentation in online environments in terms of histrionic personality. The aim of the study was to develop the Online Histrionic Personality Scale (OHPS). The OHPS was developed using the diagnostic criteria for Histrionic Personality Disorder (HPD) in the DSM-5 and assesses histrionic behavior in online environments. The present study comprised 381 university students (219 females and 162 males) from four different samples. The validity of the OHPS was investigated utilizing Exploratory Factor Analysis (EFA), Confirmatory Factor Analysis (CFA), and criterion validity. As a result of the EFA, a single-factor structure with an eigenvalue of 3.850 was found and accounted for $48.12 \%$ of the total variance. This one-dimensional structure was tested with CFA in two different samples. CFA results show that OHPS had an acceptable fit. The criterion validity of the OHPS was examined with the Desire for Being Liked Scale (DBLS) and the Histrionic Personality Belief subscale of the Personality Belief Questionnaire-Short Form (PBQSTF). Analysis showed that the OHPS was significantly associated with desire for being liked $(r=.65, p<.01)$ and histrionic personality beliefs $(r=.70, p<.01)$. The reliability of the OHPS was evaluated with Cronbach's $\alpha$ internal consistency reliability coefficient and corrected item total correlation coefficient in three different samples. The Cronbach $\alpha$ internal consistency coefficients of the OHPS were .84 (EFA sample), .88 (CFA sample), and .88 (criterion validity sample). Corrected item total correlation coefficients of OHPS ranged from .53 to .62 in the EFA sample, .47 to .78 in the CFA sample, and .52 to .76 in the criterion validity sample. The distribution of data was examined with floor and ceiling effects in three different samples. Finally, the Standard Error of Measurement (SEM) was calculated in three different samples. There was no floor and ceiling effects in the data, and the SEM values were within acceptable limits. When validity and reliability analysis of the OHPS are considered as a whole, it is concluded that the OHPS is a valid and reliable scale that assesses online histrionic personality among university students.
\end{abstract}

Keywords: Histrionic personality, histrionic personality disorder, online histrionic behavior, online histrionic personality 


\section{Introduction}

In recent years, a great deal of research has been carried out on the personality that internet users have in online environments (Akhtar, Winsborough, Ort, Johnson \& ChamorroPremuzic, 2018; Azucar, Marengo \& Settanni, 2018; Blackwell, et al., 2017). There have also been discussions on whether the personality presented in online environments and the individuals' real personalities are similar. Consequently, some researchers emphasize that online personality is similar to offline personality (Back et al., 2010; Gosling et al., 2011; Jin, 2012; Kim \& Chock, 2017; Wang, 2013) while others emphasize that online personality is an idealized personality (Blumer \& Döring, 2012; Hongladarom, 2011; Luppicini \& Haghi, 2012; Manago et al., 2008). In other words, a different personality can be present itself in online environments (Qiu et al., 2015). Indeed, Qiu et al. (2012) reported that social network users are more likely to express positive (rather than negative) emotions online and present better emotional wellbeing on Facebook than in real life.

Almost a decade ago, Back et al. (2010) compared the extended real-life hypothesis with the idealized virtual-identity hypothesis. The extended real-life hypothesis posits that individuals use online environments to communicate their real personality. Here, online personality is similar to offline personality but is a continuation of offline personality. According to the idealized virtual-identity hypothesis, individuals in online environments display idealized characteristics that do not reflect their actual personalities. The study found that personality impressions based on social media profiles in online environments reflected individuals' actual personality rather than their idealized view (Back et al., 2010). However, both hypotheses posit that personality is presented differently (at least to some extent) in online environments.

Online environments are also frequently used by individuals as a medium to present their appearance and/or idealized appearance (Brown \& Knight, 2015; Chae, 2017; Hogue \& 
Mills, 2019), to be the center of attention (Chua \& Chang, 2016; Mills et al., 2018; Ramsey \& Horan, 2018), to be liked (Coulthard \& Ogden, 2018; Rosenthal-von der Pütten et al., 2019; Sherman et al., 2018; Tiggemann \& Barbato, 2018), to reflect sexual attraction (Ramsey \& Horan, 2018; van Oosten et al., 2018; Van Oosten \& Vandenbosch, 2017), to impress others (Weeks et al., 2015; Qiu et al., 2015), to build closer relationships (Hood et al., 2018; Khalis \& Mikami, 2018; Sutcliffe et al., 2018), and to be self-manipulation (for a good impression) (Bazarova et al., 2012; Qiu et al., 2015; Qiu et al., 2012). Furthermore, online environments can affect other users and some users are easily affected psychologically in online environments (Bacev-Giles \& Haji, 2017; Pal et al., 2019). It has also been shown that some users' expressions in online environments change quickly and individuals can have opposite emotion expressions within a very short time from each other (Panger, 2017) Some of these behaviors can be indicative of histrionic behaviors in online environments. Therefore, it may be possible that some individuals have histrionic personality in online environments.

Histrionic Personality Disorder (HPD) is a pattern of pervasive and excessive emotionality and attention seeking (American Psychiatric Association [APA], 2013). The APA (2013, p. 667) diagnoses HPD according to eight diagnostic criteria (as seen in Table 1). The APA's (2013) definition of HPD can also be applied to online histrionic behavior. Considering the APA's (2013) HPD definition, Online Histrionic Personality can be described as a pattern of excessive emotionality and attention seeking in online environments. Histrionic behaviors are often observed in online environments (especially social media). Previous research has indicated that behaviors similar to diagnostic criteria of HPD can be observed online environments including the desire for center of attention (Hawk et al., 2019; Edwards, 2017), inappropriate behaviors (sexually seductive or provocative behavior) (Choate, 2014; van Oosten et al., 2018), emotional lability (Panger, 2017), using physical appearance (to draw attention to self) (Fardouly et al., 2017; Hogue \& Mills, 2019), excessively 
impressionistic behaviors (Carpenter, 2012; Panek et al., 2013; Singh et al., 2018), manipulative behaviors (Ellison et al., 2006; Qiu et al., 2015; Qiu et al., 2012), being easily influenced (by online persons or content) (Bacev-Giles \& Haji, 2017; Stieglitz \& Dang-Xuan, 2013), and need for closer relationship (Butler \& Matook, 2015). Consequently, having a histrionic personality is possible in online environments.

There are many psychometric scales in the psychological literature that are associated with online histrionic behaviors including, scales for online self-presentation (Guohua et al., 2012; Yang \& Bradford- Brown, 2015), online risky behaviors (Branley \& Covey, 2018; Lau \& Yuen, 2013), online intensity (Ellison et al., 2007; Orosz et al., 2016), online sociality (Hughes et al., 2017), and online self-disclosure (Pang, 2018; Schouten et al., 2007). Given that histrionic behavior is characterized by histrionic personality (APA, 2013), it should be the case that online histrionic behaviors are characterized by online histrionic personality. Online histrionic behaviors appear to be a reflection of online histrionic personality. Some research conducted in recent years supports this idea. These studies show that online behavior is related to online personalities (e.g., Craker \& March, 2016; Gosling et al., 2011; Kowalski, Giumetti, Schroeder \& Lattanner, 2014; Sest \& March, 2017; Sorokowski et al., 2016; Van Geel, Goemans, Toprak \& Vedder, 2017). The present study is based on the hypothesis that online histrionic behavior contributes to the development of online histrionic personality as a consistent pattern. In other words, online histrionic behaviors cannot be considered independent of online histrionic personality, and such behaviors stem from such a personality pattern. The primary aim of the present study was to develop and validate the Online Histrionic Personality Scale (OHPS) to assess online histrionic personality. 


\section{Methods}

\section{Participants}

The present study comprised 381 university students (219 females and 162 males) from four different samples. The pilot study sample comprised 53 university students (33 females, 20 males). The scale validity studies were performed on 328 university students (186 females, 142 males) across three different samples. The scale validity was analyzed utilizing exploratory factor analysis (EFA), confirmatory factor analysis (CFA), and criterion validity. The EFA sample comprised 100 university students (57 females and 43 males). The CFA sample comprised 105 university students (55 females, 50 males). The criterion validity sample comprised 123 university students (74 females, 49 males). In all samples, university students were aged 18-31 years. All of the data were collected from students in Firat University (Turkey). Students' use of online environments was predetermined as the key inclusion criterion. Students who did not use the online environments and did not want to participate in the study were excluded. A total of 24 students declined to participate in the study $(94.1 \%$ response rate).

\section{Materials}

Online Histrionic Personality Scale (OHPS): In the present study, the OHPS was developed by using the diagnostic criteria for HPD in DSM-5 (APA, 2013). The OHPS is a self-report type scale where participants evaluate some of their online behavior and was developed utilizing a non-clinical sample. The main purpose of the OHPS is to assess the histrionic tendencies (in the online environment) of the participants as self-report. Therefore, the OHPS assesses histrionic personality in online environments. OHPS is not a scale that clinicians can use to diagnose. The diagnostic criteria of HPD that clinicians will consider have been converted into items for participants to evaluate themselves. 
The OHPS comprises eight items and one dimension (i.e., online HPD), and is rated on a 5point Likert-type scale ( $1=$ not suitable at all, $5=$ completely suitable). Findings on the validity and reliability of OHPS are presented in the Results section. The scales introduced below were used for criterion validity of the OHPS.

Desire for Being Liked Scale (DBLS): The DBLS was developed by Kaşıkara and Doğan (2017). The DBLS is a unidimensional scale comprising nine items and rated on a four-point scale that explained $42 \%$ of variance. This structure of the DBLS was confirmed by CFA $\left(\chi^{2} / \mathrm{SD}=1.42, \mathrm{RMSEA}=.06, \mathrm{GFI}=.92, \mathrm{AGFI}=.88, \mathrm{CFI}=.95, \mathrm{IFI}=.96, \mathrm{NFI}=.87, \mathrm{RFI}=.83\right.$, $\mathrm{RMR}=.03, \mathrm{SRMR}=.06$ ). The Cronbach's alpha internal consistency coefficients of the DBLS were found to be .82 and .81 (Kaşıkara \& Doğan, 2017). The nine-item and unidimensional structure of the DBLS was tested in the present study. The CFA results showed that the DBLS had relatively acceptable compliance values $\left[\left(\chi^{2}=59.620, \mathrm{df}=25, \chi^{2} / \mathrm{df}=2.385, p<.001\right.\right.$, RMSEA $=.107, \mathrm{GFI}=.89, \mathrm{AGFI}=.81, \mathrm{CFI}=.89, \mathrm{IFI}=.90$ and $\mathrm{TLI}(\mathrm{NNFI})=.84]$. In the present study, the Cronbach's alpha internal consistency reliability coefficient of the DBLS was .81 .

Personality Belief Questionnaire-Short Form (PBQ-STF): In the present study, the Histrionic Personality Belief subscale of the PBQ-STF was used. The PBQ-STF was developed by Beck and Beck (1991) and adapted into Turkish by Taymur et al. (2011). The structural validity of PBQ-STF was examined by EFA and criterion validity. The PBQ-STF comprises 65 items and nine sub-dimensions. The criterion validity of the PBQ-STF was assessed using the Dysfunctional Attitude Scale (DAS-A) (Şahin \& Şahin, 1992) and the Temperament and Character Inventory (TCI) (Köse et al., 2004). The reliability of PBQ-STF was assessed by Cronbach's alpha coefficient and test-retest. As a result of the reliability analysis, PBQ-STF was found to be a reliable scale. High scores on the scale indicate a high level of the 
characteristic in each related subscale (Taymur et al., 2011). The seven-item and onedimensional structure of the Histrionic Personality Belief subscale was tested in the present study. The CFA results showed that the subscale of Histrionic Personality Belief subscale had relatively acceptable fit values $\left[\left(\chi^{2}=31.190, \mathrm{df}=13, \chi^{2} / \mathrm{df}=2.399, p<.01, \mathrm{RMSEA}=.107\right.\right.$, $\mathrm{GFI}=.94, \mathrm{AGFI}=.86, \mathrm{CFI}=.93, \mathrm{IFI}=.93$ and $\mathrm{TLI}(\mathrm{NNFI})=.88]$. In the present study, the Cronbach alpha internal consistency reliability coefficient of the Histrionic Personality Belief subscale was .80 .

\section{Procedure and ethics}

In the present study, the ethics committee approval and application permission were obtained the first author's university ethics committee. Then, the OHPS was developed using the eight diagnostic criteria for HPD in DSM-5 (APA, 2013). The diagnostic criteria of HPD were adapted to the online environment with eight items relating to the eight diagnostic criteria. Five researchers in the field of cyberpsychology examined the eight-item draft of the OHPS. Changes were made to OHPS by taking into consideration the suggestions of the researchers. After the proposed changes were made, the OHPS was presented to the same group again. At this stage, the eight-item OHPS was agreed. The OHPS was then examined in terms of clarity via a pilot study. The pilot study was carried out with 53 university students. The pilot study was carried out to determine whether the items, instructions, and response options of the OHPS were understood by the target sample. The final version of OHPS was produced following the feedback from the university students. The final version of the OHPS and the items' relationship with each DSM-5 criterion for HPD are presented in Table 1. Finally, data were collected for the validity and reliability of OHPS. 
The aim of the study was explained to the participants, and written informed consent was provided by all students. The data were collected voluntarily in the classes where the students were educated. The data collection process lasted approximately 20 minutes.

\section{Data analysis}

The structural validity of OHPS was investigated by EFA and CFA. First, EFA was followed by CFA. Kaiser-Meyer-Olkin (KMO) coefficient and Barlett's Sphericity Test were performed before EFA. As a result of the analysis, it was found that the dataset was suitable for EFA. Principal Component Analysis was used in the EFA. The structure obtained as a result of EFA was tested with CFA. Sample size, multiple linearity, multicollinearity, and multiple normality were investigated before CFA. As a result of the analysis, it was found that the dataset was suitable for CFA. The model of OHPS was tested with the covariance matrix using the Maximum Likelihood method. The model fit was examined with $\chi^{2} / \mathrm{df}$, RMSEA, GFI, CFI, IFI and TLI (NNFI) fit indices. Commonly accepted fit indices and acceptable limits for model fit are presented in Table 2 along with a description of each acronym.

The criterion validity of the OHPS was evaluated using the DBLS and PBQ-STF (more specifically the Histrionic Personality Belief subscale was used). In recent studies, the DBLS has been found to be highly related to histrionic personality (Savci et al., 2019). Therefore, the DBLS was used in the criterion validity of OHPS. Also, the PBQ-STF is a personality belief scale. In the present study, the Histrionic Personality Belief subscale of PBQ-STF was used. While developing PBQ-STF, HPD was used for criterion validity (Butler et al., 2007). Therefore, PBQ-STF was used in the criterion validity of OHPS.

The reliability of OHPS was evaluated with Cronbach $\alpha$ internal consistency reliability coefficient and corrected item total correlation coefficients. The distribution of data was examined with floor and ceiling effects. The floor effect shows the percentage of individuals who received a total of 8 points by answering "1" (not suitable at all) to all items. The floor 
ceiling shows the percentage of individuals who received a total of 40 points by answering "5" (completely suitable) to all items. Finally, the Standard Error of Measurement (SEM) was calculated. SEM reflects the degree to which the observed scores obtained on the OHPS fluctuate as a result of the errors of measurement. SPSS and AMOS programs were used to analyze the data. The procedure, ethics, and data analysis scheme is presented in Figure 1.

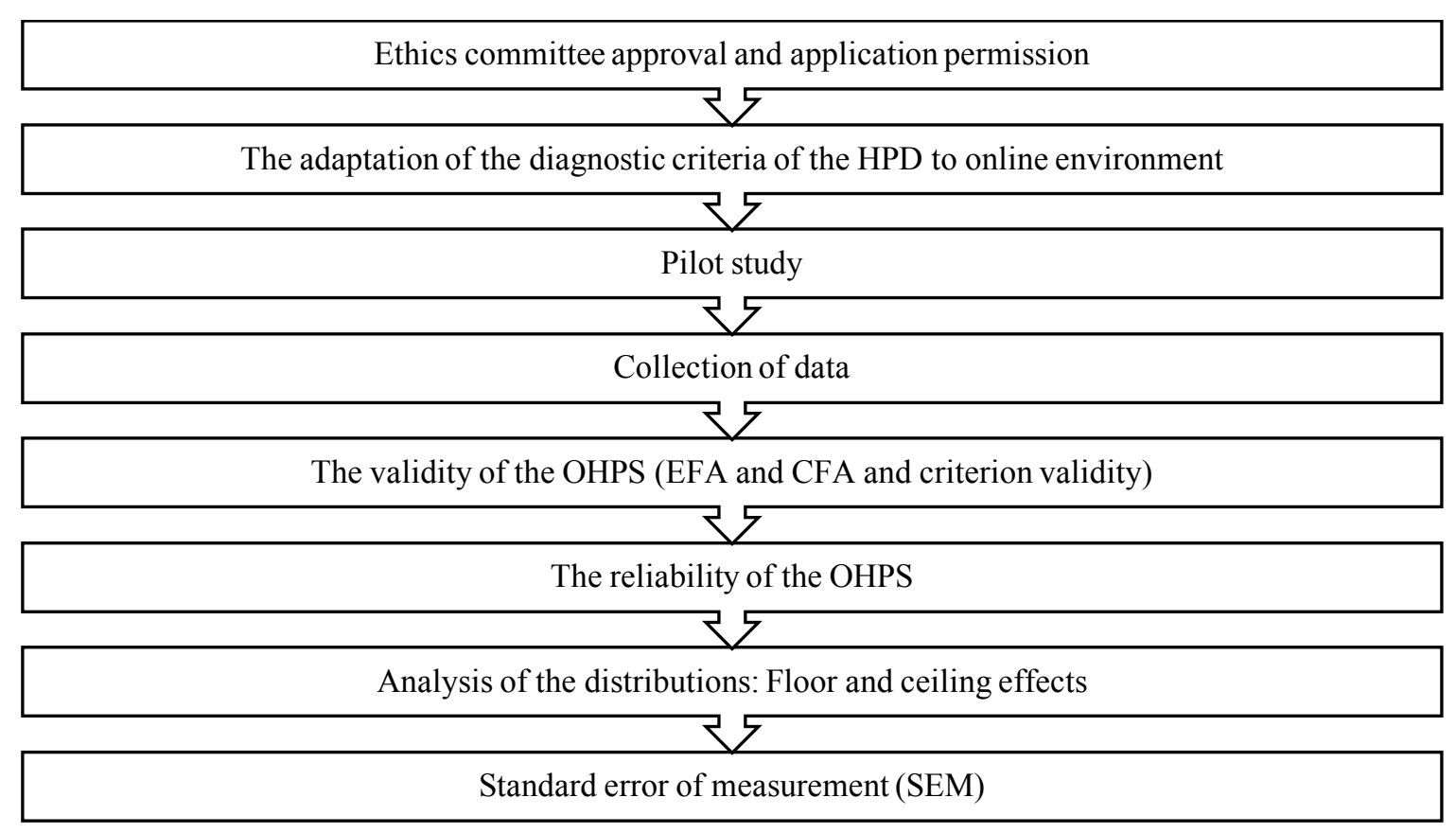

Figure 1. Procedure, Ethics, and Data Analysis Scheme 
Table 1. OHPS final form and relationship with Histrionic Personality Disorder

\begin{tabular}{|c|c|c|c|}
\hline DSM-5 English* & DSM-5 Turkish** & OHPS-Turkish & OHPS-English \\
\hline $\begin{array}{l}\text { 1. Is uncomfortable in } \\
\text { situations in which he or } \\
\text { she is not the center of } \\
\text { attention. }\end{array}$ & $\begin{array}{l}\text { 1-İlgi odağı olmadığ } 1 \\
\text { durumlarda rahatsız olur. }\end{array}$ & $\begin{array}{l}\text { 1. Online ortamlarda ilgi } \\
\text { odağı olmadiğımda } \\
\text { rahatsı olurum. }\end{array}$ & $\begin{array}{l}\text { 1. I am uncomfortable } \\
\text { when I am not the center } \\
\text { of attention in online } \\
\text { environments. }\end{array}$ \\
\hline $\begin{array}{l}\text { 2. Interaction with others } \\
\text { is often characterized by } \\
\text { inappropriate sexually } \\
\text { seductive or provocative } \\
\text { behavior. }\end{array}$ & $\begin{array}{l}\text { 2-Başkalarıyla olan } \\
\text { etkileşimleri, cinsel } \\
\text { yönden, ayartıcı, kışkırtıcı } \\
\text { ya da baştan çıartıcı, } \\
\text { uygunsuz davranışlarla } \\
\text { belirlidir. }\end{array}$ & $\begin{array}{l}\text { 2. Online ortamlarda } \\
\text { başkaları ile olan } \\
\text { etkileşimlerimde baştan } \\
\text { çıkartıcı davranırım. }\end{array}$ & $\begin{array}{l}\text { 2. I act seductively in my } \\
\text { interactions with others in } \\
\text { online environments. }\end{array}$ \\
\hline $\begin{array}{l}\text { 3. Displays rapidly } \\
\text { shifting and shallow } \\
\text { expression of emotions. }\end{array}$ & $\begin{array}{l}\text { 3-Birden değişen, } \\
\text { yüzeysel (sığ) duygular } \\
\text { gösterir. }\end{array}$ & $\begin{array}{l}\text { 3. Online ortamlarda } \\
\text { duygularım bir anda } \\
\text { değişir. }\end{array}$ & $\begin{array}{l}\text { 3. My emotions change } \\
\text { rapidly in online } \\
\text { environments }\end{array}$ \\
\hline $\begin{array}{l}\text { 4. Consistently uses } \\
\text { physical appearance to } \\
\text { draw attention to self. }\end{array}$ & $\begin{array}{l}\text { 4-İlgi çekmek için sürekli } \\
\text { olarak dış görünümünü } \\
\text { kullanır. }\end{array}$ & $\begin{array}{l}\text { 4. Online ortamlarda ilgi } \\
\text { çekmek için sürekli } \\
\text { olarak dış görünümümü } \\
\text { kullanırım. }\end{array}$ & $\begin{array}{l}\text { 4. I consistently use my } \\
\text { physical appearance to } \\
\text { draw attention in online } \\
\text { environments. }\end{array}$ \\
\hline $\begin{array}{l}\text { 5. Has a style of speech } \\
\text { that is excessively } \\
\text { impressionistic and } \\
\text { lacking in detail. }\end{array}$ & $\begin{array}{l}\text { 5-Gereğinden çok } \\
\text { etkilemeye yönelik ve } \\
\text { ayrıntıdan yoksun bir } \\
\text { konuşma biçimi vardır. }\end{array}$ & $\begin{array}{l}\text { 5. Online ortamlardaki } \\
\text { davranışlarım (paylaşım, } \\
\text { yorum, resim, video vb.) } \\
\text { başkalarını etkilemeye } \\
\text { yöneliktir. }\end{array}$ & $\begin{array}{l}\text { 5. My behaviors in online } \\
\text { environments are oriented } \\
\text { to influencing others } \\
\text { (sharing, comments, } \\
\text { images, videos, etc.). }\end{array}$ \\
\hline $\begin{array}{l}\text { 6. Shows self- } \\
\text { dramatization, } \\
\text { theatricality, and } \\
\text { exaggerated expression of } \\
\text { emotion. }\end{array}$ & $\begin{array}{l}\text { 6-Yapmacık davranır, } \\
\text { gösteriş yapar ve } \\
\text { duygularını abartılı } \\
\text { gösterir. }\end{array}$ & $\begin{array}{l}\text { 6. Online ortamlarda } \\
\text { yapmacık davranır, } \\
\text { gösteriş yapar ve } \\
\text { duygularımı abartırım. }\end{array}$ & $\begin{array}{l}\text { 6. I show off and } \\
\text { exaggerate my emotion in } \\
\text { online environments. }\end{array}$ \\
\hline $\begin{array}{l}\text { 7. Is suggestible (i.e., } \\
\text { easily influenced by } \\
\text { others or circumstances). }\end{array}$ & 7-Kolay etki altında kalır. & $\begin{array}{l}\text { 7. Online ortamlarda } \\
\text { başkaları beni kolaylıkla } \\
\text { etkileyebilir. }\end{array}$ & $\begin{array}{l}\text { 7. Others can easily } \\
\text { influence me in online } \\
\text { environments. }\end{array}$ \\
\hline $\begin{array}{l}\text { 8. Considers relationships } \\
\text { to be more intimate than } \\
\text { they actually are. }\end{array}$ & $\begin{array}{l}\text { 8-İlişkilerin, olduğundan } \\
\text { daha yakın olması } \\
\text { gerektiğini düşünür. }\end{array}$ & $\begin{array}{l}\text { 8. Online ortamlarda } \\
\text { ilişskilerimin daha yakın } \\
\text { olması gerektiğini } \\
\text { düşünürüm. }\end{array}$ & $\begin{array}{l}8 . \text { I think my relationships } \\
\text { are more intimate in } \\
\text { online environments. }\end{array}$ \\
\hline
\end{tabular}

* DSM-5-English (APA, 2013)

**DSM-5-Turkish (Köroğlu, 2014) 
Table 2. Goodness of fit indices and acceptable limits

\begin{tabular}{ll}
\hline Indices & Acceptable limits \\
\hline$\chi^{2} / \mathrm{df}$ & $\leq 5$ acceptable fit, $\leq 3$ perfect fit \\
RMSEA & $\leq 0.10$ weak fit, $\leq 0.08$ good fit, $\leq 0.05$ perfect fit \\
GFI & $.85-.89$ acceptable fit, $\geq .90$ good fit \\
AGFI & $.85-.89$ acceptable fit, $\geq .90$ good fit \\
CFI & $\geq .90$ acceptable fit, $\geq .95$ good fit, $\geq .97$ perfect fit \\
IFI & $\geq .90$ acceptable fit, $\geq .95$ good fit, $\geq .97$ perfect fit \\
TLI (NNFI) & $\geq .90$ acceptable fit, $\geq .95$ good fit \\
\hline (Brown, 2006; Cokluk, Sekercioglu \& Buyukozturk, 2012; Hu \& Bentler, 1999; Kelloway, 2015; Kline, 2011; Raykov \& Marcoulides, 2008; \\
Meydan \& Sesen, 2011; Schumacker \& Lomax, 2004; Schermelleh-Engel et al., 2003, Sümer, 2000; Simsek, 2007; Tabachnick \& Fidell, \\
2013; Thompson, 2004) (as cited in Savci \& Aysan, 2019) [ $\chi^{2}=$ Chi-Square, df=degrees of freedom, RMSEA=The Root Mean Square Error \\
of Approximation, GFI=Goodness of Fit Index, AGFI=Adjusted Goodness of fit Index, CFI=Confirmatory Fit Index, IFI=Incremental Fit \\
Index, TLI (NNFI)=Tucker Lewis Index (NNFI= Non-Normed Fit Index)]
\end{tabular}

\section{Results}

\section{Pilot study}

A pilot study was conducted with university students to evaluate the items, instructions, and response options of OHPS. The pilot study sample comprised 53 university students (30 females, 20 males). Pilot study was carried out face to face. Participants were given OHPS and asked to read. Firstly, the concepts of "online" and "online environment" were explained. Then OHPS was distributed then to students. The students were given the opportunity to evaluate the items, instructions, and response options of OHPS. As a result of the pilot study, the students evaluated all items, instructions, and response options of the OHPS as understandable.

\section{Scale validity}

Exploratory factor analysis (EFA): The structural validity of the OHPS was first investigated with EFA. EFA was carried out on 100 university students (57 females, 43 males). The suitability of the dataset for EFA was examined with the Kaiser-Meyer-Olkin (KMO) coefficient and Barlett's Sphericity Test. As a result of the analysis, it was found that the dataset was suitable for EFA [(The Kaiser-Meyer-Olkin (KMO) coefficient=.80 and Barlett's Sphericity Test $\left.\left.\chi^{2}=278.688, p<.001\right)\right]$. EFA was then performed on eight items using Principal 
Component Analysis. As a result of the EFA, a single-factor structure with an eigenvalue of 3.850 was found and accounted for $48.12 \%$ of the total variance. In addition, a scree plot was analyzed. As shown in the graph (Figure 1), the OHPS comprised a single dimension. When the line graph shown is examined, it can be seen that the graph continues in a horizontal plane after the first break. Breakage occurs after the first factor. Finally, the factor loadings of OHPS were examined. Accordingly, the factor load values of the OHPS varied between .65 and .73. The scree plot of the OHPS is presented in Figure 2, and the EFA results are shown in Table 3.

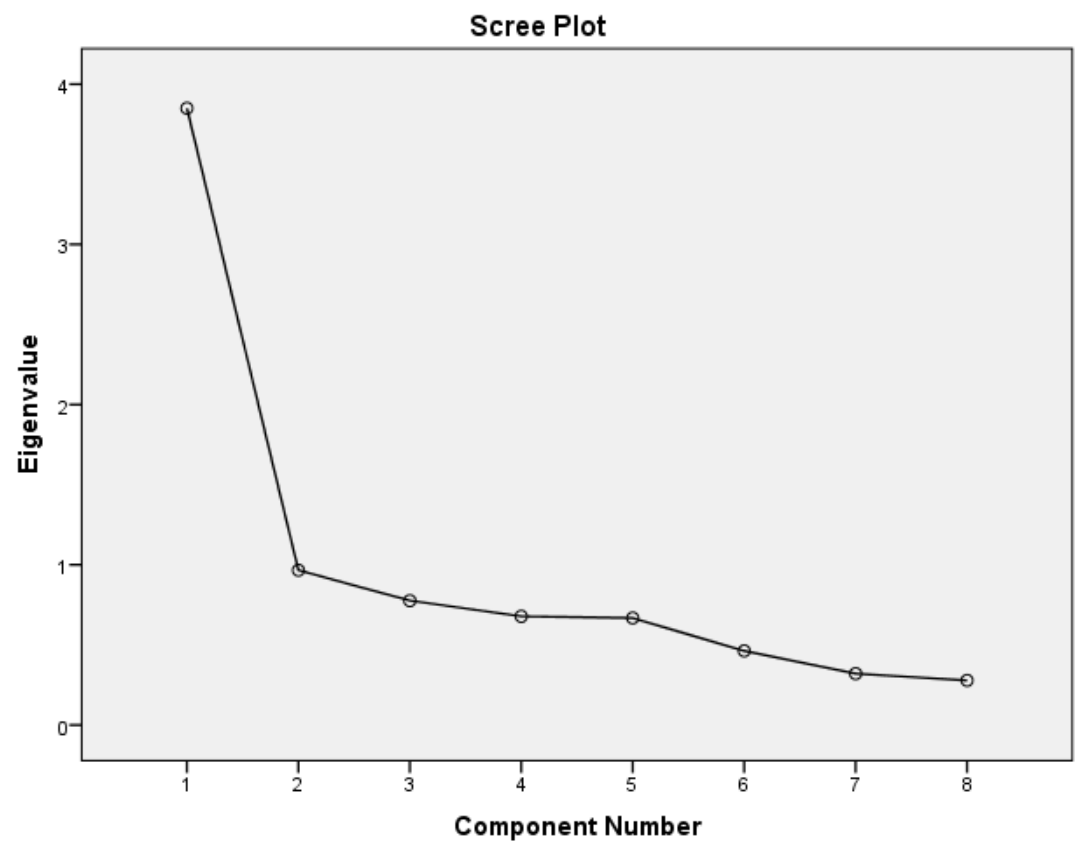

Figure 2. The scree plot of the Online Histrionic Personality Scale

Table 3. The EFA results of Online Histrionic Personality Scale

\begin{tabular}{clccc}
\hline & Items & Factor Loading & \% of Variance & Eigenvalue \\
\hline & 1 & .73 & & \\
& 2 & .65 & & \\
& 3 & .66 & & \\
& 4 & .70 & & \\
& 5 & .72 & & \\
& 6 & .72 & & \\
& 7 & .65 & & \\
& 8 & .72 & & \\
\hline
\end{tabular}


Confirmatory factor analysis (CFA): The unidimensional structure of the OHPS was tested with CFA. CFA was carried out on 105 university students (55 females, 50 males). As a result of CFA, the OHPS model had good fit index values $\left[\left(\chi^{2}=41.544, \mathrm{df}=20, \chi^{2} / \mathrm{df}=2.077, p=.003\right.\right.$, $\mathrm{RMSEA}=.10, \mathrm{GFI}=.90, \mathrm{AGFI}=.83, \mathrm{CFI}=.94, \mathrm{IFI}=.94$ and $\mathrm{TLI}(\mathrm{NNF} 1)=.92]$. The factor loadings of OHPS for CFA ranged between .47 and .88. The path diagram of the OHPS in the CFA sample is presented in Figure 3. The eight-item and one-dimensional structure of OHPS was also tested on the data collected for criterion validity. The CFA results obtained from this sample showed that the OHPS model had relatively good fit $\left[\left(\chi^{2}=61.366, \mathrm{df}=20, \chi^{2} / \mathrm{df}=3.068\right.\right.$, $p<.001, \mathrm{RMSEA}=.130, \mathrm{GFI}=.90, \mathrm{AGFI}=.81, \mathrm{CFI}=.91, \mathrm{IFI}=.91$ and $\mathrm{TLI}(\mathrm{NNFI})=.87]$. The factor loadings of OHPS in the sample ranged between .56 and .83 . The path diagram in the OHPS criterion validity sample is presented in Figure 4. As a result, it was found that the eight-item unidimensional structure of the OHPS was confirmed in two different samples. The CFA results are shown in Table 4.

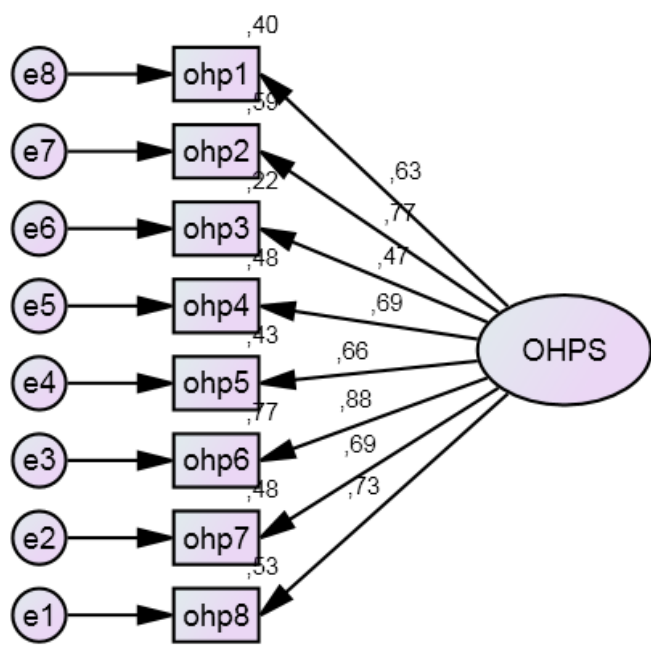

Figure 3. Model of the OHPS in the CFA sample

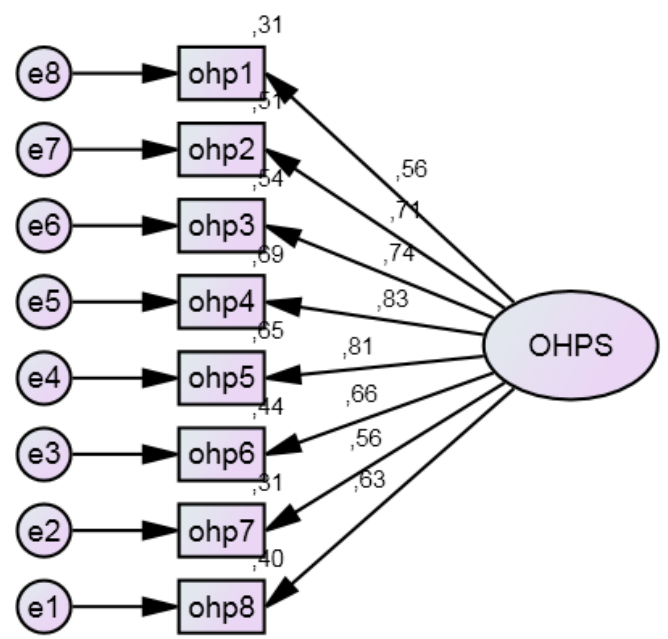

Figure 4. Model of OHPS in the criteria validation sample 
Table 4. The CFA Results of Online Histrionic Personality Scale

\begin{tabular}{lcccccc}
\hline & \multicolumn{3}{c}{ CFA Sample } & \multicolumn{3}{c}{ Criterion Validity Sample } \\
\cline { 2 - 7 } & $\lambda$ & $\mathrm{R}^{2}$ & $T$ & $\lambda$ & $\mathrm{R}^{2}$ & $T$ \\
\cline { 2 - 7 } OHPS $\rightarrow$ ohp1 & .63 & .40 & & .56 & .31 & \\
OHPS $\rightarrow$ ohp2 & .77 & .59 & 6.803 & .71 & .51 & 5.378 \\
OHPS $\rightarrow$ ohp3 & .47 & .22 & 8.618 & .74 & .54 & 6.207 \\
OHPS $\rightarrow$ ohp4 & .69 & .48 & 6.448 & .83 & .69 & 7.198 \\
OHPS $\rightarrow$ ohp5 & .66 & .43 & 6.810 & .81 & .65 & 7.340 \\
OHPS $\rightarrow$ ohp6 & .88 & .77 & 4.573 & .66 & .44 & 6.726 \\
OHPS $\rightarrow$ ohp7 & .69 & .48 & 7.592 & .56 & .31 & 6.577 \\
OHPS $\rightarrow$ ohp8 & .73 & .53 & 6.196 & .63 & .40 & 5.363 \\
\hline$* * * p<.001$ & & & & & &
\end{tabular}

Criterion Validity: The criterion validity of the OHPS was examined with the Desire for Being Liked Scale (DBLS) and the Histrionic Personality Belief subscale of the Personality Belief Questionnaire-Short Form (PBQ-STF). The criterion validity of OHPS was carried out on 123 university students (74 females, 49 males). Pearson's Product-Moment Correlation Analysis showed that the OHPS was significantly associated with desire for being liked $(\mathrm{r}=.65, p<.01)$ and histrionic personality beliefs $(\mathrm{r}=.70, p<.01)$.

\section{Scale reliability}

The reliability of the OHPS was evaluated with Cronbach $\alpha$ internal consistency reliability coefficient and corrected item total correlation coefficient in the EFA sample, CFA sample and criterion validity sample. The Cronbach $\alpha$ internal consistency coefficients of the OHPS were .84 (EFA sample), .88 (CFA sample), and .88 (criterion validity sample). Corrected item total correlation coefficients of OHPS ranged from .53 to .62 in the EFA sample, .47 to .78 in the CFA sample, and .52 to .76 in the criterion validity sample. 


\section{Analysis of the distributions: Floor and ceiling effects}

Floor and ceiling effects of the OHPS were evaluated in three different samples (EFA, CFA, and criterion validity). The floor effect shows the percentage of individuals who received a total of 8 points by answering "1" (not suitable at all) to all items. The floor ceiling shows the percentage of individuals who received a total of 40 points by answering "5" (completely suitable) to all items. Both floor and ceiling rate should be below $15 \%$. When these rates are above 15\%, floor and ceiling effects are observed (Pontes \& Griffiths, 2015). This situation negatively affects the validity and reliability of the scale. In this study, floor effect was calculated as $11 \%(\mathrm{n}=11)$ in the EFA sample, $11 \%(\mathrm{n}=12)$ in the CFA sample and $15 \%(n=19)$ in the criterion validity sample. Ceiling effect was calculated as $1 \%(n=1)$ in the EFA sample, $2 \%(n=2)$ in the CFA sample and $0 \%(n=0)$ in the criterion validity sample. Consequently, there was no floor and ceiling effects in the data.

\section{Standard error of measurement (SEM)}

The SEM was calculated because it reflects the degree to which the observed scores obtained on the OHPS fluctuate as a result of the errors of measurement (Morrow et al., 2015). The SEM was computed by the standard deviation of the measure multiplied by the square root of one minus its reliability coefficient (Morrow et al., 2015). SEM $\leq \mathrm{SD} / 2$ was taken as the criterion of acceptable precision (Wuang et al., 2011; Wyrwich et al., 1999). The lower the reliability, the greater the SEM, and the less precise the measure. In this study, it was calculated as $\mathrm{SEM} \leq \mathrm{SD} / 2$ in the EFA sample $[(\sqrt{ } 1-.84=.25 ; \mathrm{SEM}=(\mathrm{SD}) 5.51 \times .25=1.38$; $\mathrm{SD} / 2=2.76 ; 1.38 \leq 2.76 ; \mathrm{SEM} \leq \mathrm{SD} / 2)], \mathrm{CFA}$ sample $[(\sqrt{ } 1-.88=.35 ; \mathrm{SEM}=(\mathrm{SD}) 6.52 \times .35=2.28$; $\mathrm{SD} / 2=3.26 ; 2.28 \leq 3.26 ; \mathrm{SEM} \leq \mathrm{SD} / 2)]$ and criterion validity sample $[(\sqrt{ } 1-.88=.35 ; \mathrm{SEM}=(\mathrm{SD})$ $6.99 \times .35=2.45 ; \mathrm{SD} / 2=3.5 ; 2.45 \leq 3.5 ; \mathrm{SEM} \leq \mathrm{SD} / 2)]$. Consequently, the $\mathrm{SEM}$ values were deemed to be within acceptable limits. 


\section{Discussion}

Research shows that behavior and activities in offline environments can be performed in offline environments, and that the same activities or behaviors may differ depending whether they are online or offline. As mentioned previously, such behaviors and activities include online security behaviors, online shopping, online bullying, online prosocial behaviors, online sexual behaviors, problematic online behaviors, risky online behaviors, online gaming, online gambling, cyberchondria, cyberstalking, online self-presentation, and online antisocial behaviors. The aim of the study was to develop the Online Histrionic Personality Scale (OHPS). The OHPS was developed using the diagnostic criteria for Histrionic Personality Disorder (HPD) in the DSM-5 (APA, 2013) and assesses histrionic behavior in online environments.

The structural validity of OHPS was investigated utilizing both EFA and CFA. The criterion validity of the OHPS was evaluated using the DBLS and PBQ-STF. The reliability of OHPS was evaluated with Cronbach $\alpha$ internal consistency reliability coefficient and corrected item total correlation coefficients. The distribution of data was examined with floor and ceiling effects. Finally, the Standard Error of Measurement (SEM) was calculated. As a result of the analyses, it was seen that OHPS explained a high level of variance for a onedimensional scale. Also, the one-dimensional structure was confirmed by EFA. This finding shows that the OHPS structure is stable. Criterion validity results show that the OHPS assesses the construct it targets. In addition, the OHPS had a relatively high level of criterion validity. Cronbach's $\alpha$ internal consistency reliability coefficient and corrected item total correlation coefficients showed that the OHPS had a high level of reliability (Buyukozturk, 2010, Cokluk et al., 2012; Kline, 1994; Tabachnick \& Fidell, 2013). Floor and ceiling effects of the OHPS were evaluated in three different samples (EFA, CFA, and criterion validity), and there were no floor and ceiling effects in the data. Finally, SEM was utilized to assess the 
degree to which the observed scores obtained on the OHPS fluctuated as a result of the errors of measurement. The SEM values were within acceptable limits.

The OHPS can be used by researchers to evaluate online histrionic personality traits of university students. The OHPS can be used in descriptive studies, especially among nonclinical samples. There is no alternative scale to the OHPS. Therefore, it is envisaged that the OHPS will be used frequently in the field of cyberpsychology.

\section{Strengths, limitations, and future research}

The OHPS was developed using the diagnostic criteria of the HPD (APA, 2013). Consequently, the OHPS was developed by taking into consideration accepted HPD criteria. The diagnosis criteria of HPD are known and accepted worldwide. The OHPS can be easily adapted to different cultures in order to assess the online histrionic personality. Therefore, the OHPS can facilitate intercultural and online histrionic research. Powerful analyses were used in different samples when developing OHPS. The OHPS is a unidimensional scale comprising of just eight items so is therefore a scale with brevity that will help alleviate survey fatigue.

Although the OHPS is a psychometrically robust scale based on the findings presented here, it has some limitations. The OHPS is a self-report scale and self-report is open to wellknown biases such as memory recall and social desirability biases (although this cannot be overcome when using psychometric testing because all data are self-report). In addition, the criterion validity of OHPS was examined with self-reporting scales that assess offline behaviors and should be considered as a limitation when interpreting the findings. The reliability and validity of OHPS was also carried out using non-representative, non-clinical convenience samples of Turkish university students. Finally, whether or not the OHPS provides consistent results over time has yet to be investigated. Consequently, future research needs to confirm the scale's unidimensional factor structure with larger and more nationally 
representative cross-cultural samples, as well as with clinical samples. The reliability of OHPS was only examined using Cronbach $\alpha$ internal consistency coefficients. Future studies should include test-retest reliability to assess whether the OHPS provides stable results over time. It should also be noted that the translation of the OHPS did not involve any formal backtranslation process. The English items of the OHPS were translated by researchers who were fluent in both English and Turkish. However, the authors are confident that the translated items are robust and that additional back translation would not result in any significant change to the wording in the OHPS. Overall, the findings of the present study indicate that the OHPS is a valid and reliable scale for assessing online histrionic personality among university students.

Ethics committee approval: Ethics committee approval was obtained for this study. The authors report that the study was conducted in accordance with the Helsinki Declaration.

Informed consent: The Informed Consent Form was read by the researcher in the classroom environment.

Conflict of Interest: No conflict of interest was declared by the authors.

Financial disclosure: The authors declare that this study received no financial support. 


\section{References}

Akhtar, R., Winsborough, D., Ort, U., Johnson, A., \& Chamorro-Premuzic, T. (2018). Detecting the dark side of personality using social media status updates. Personality and Individual Differences, 132, 90-97. doi:10.1016/j.paid.2018.05.026.

American Psychiatric Association (2013). Diagnostic and Statistical Manual of Mental Disorders-5 (fifth edition). Arlington: American Psychiatric Publishing. (Translation, Köroğlu, E. (2014). Ankara: HBY Yayıncılık).

Azucar, D., Marengo, D., \& Settanni, M. (2018). Predicting the Big 5 personality traits from digital footprints on social media: A meta-analysis. Personality and Individual Differences, 124, 150-159. doi:10.1016/j.paid.2017.12.018.

Bacev-Giles, C., \& Haji, R. (2017). Online first impressions: Person perception in social media profiles. Computers in Human Behavior, 75, 50-57. doi:10.1016/j.chb.2017.04.056.

Back, M. D., Stopfer, J. M., Vazire, S., Gaddis, S., Schmukle, S. C., Egloff, B., \& Gosling, S. D. (2010). Facebook profiles reflect actual personality, not self-idealization. Psychological Science, 21(3), 372-374. doi:10.1177/0956797609360756.

Bazarova, N. N., Taft, J. G., Choi, Y. H., \& Cosley, D. (2012). Managing impressions and relationships on Facebook. Journal of Language and Social Psychology, 32(2), 121141. doi:10.1177/0261927x12456384.

Beck, A. T., Beck, J. S. (1991). The Personality Belief Questionnaire (unpublished assessment instrument). Bala Cynwyd, PA: The Beck Institute for Cognitive Therapy and Research.

Blackwell, D., Leaman, C., Tramposch, R., Osborne, C., \& Liss, M. (2017). Extraversion, neuroticism, attachment style and fear of missing out as predictors of social media use 
and addiction. Personality and Individual Differences, 116, 69-72. doi:10.1016/j.paid.2017.04.039.

Blumer, T., \& Döring, N. (2012). Are we the same online? The expression of the five factor personality traits on the computer and the internet. Cyberpsychology: Journal of Psychosocial Research on Cyberspace, 6(3), doi.org/10.5817/CP2012-3-5

Branley, D. B., \& Covey, J. (2018). Risky behavior via social media: The role of reasoned and social reactive pathways. Computers in Human Behavior, 78, 183-191. doi:10.1016/j.chb.2017.09.036.

Brown, A., \& Knight, T. (2015). Shifts in media images of women appearance and social status from 1960 to 2010: A content analysis of beauty advertisements in two Australian magazines. Journal of Aging Studies, 35, 74-83. doi:10.1016/j.jaging.2015.08.003.

Butler, A. C., Cohen, L. H., Beck, A.T. (2007). The Personality Belief Questionnaire-Short Form: Development and preliminary findings. Cognitive Therapy and Research, 31, $357-370$.

Butler, B. S., \& Matook, S. (2015). Social media and relationships. In: Mansell, R. \& Ang, P. H. (Eds.), The international encyclopedia of digital communication and society (pp. 112). Hoboken, NJ: John Wiley \& Sons, Inc. doi:10.1002/9781118767771.wbiedcs097. Buyukozturk, Ş. (2010). Manual of data analysis for social sciences (in Turkish). Ankara: Pegem Publishing.

Carpenter, C. J. (2012). Narcissism on Facebook: Self-promotional and anti-social behavior. Personality and Individual Differences, 52(4), 482-486. doi:10.1016/j.paid.2011.11.011. 
Chae, J. (2017). Virtual makeover: Selfie-taking and social media use increase selfie-editing frequency through social comparison. Computers in Human Behavior, 66, 370-376. doi:10.1016/j.chb.2016.10.007.

Choate, L. H. (2014). Adolescent girls in distress: A guide for mental health treatment and prevention. New York: Springer.

Choi, D.-H., \& Shin, D.-H. (2017). Exploring political compromise in the new media environment: The interaction effects of social media use and the Big Five personality traits. Personality and Individual Differences, 106, 163-171. doi:10.1016/j.paid.2016.11.022.

Chua, T. H. H., \& Chang, L. (2016). Follow me and like my beautiful selfies: Singapore teenage girls' engagement in self-presentation and peer comparison on social media. Computers in Human Behavior, 55, 190-197. doi:10.1016/j.chb.2015.09.011.

Cokluk, Ö., Sekercioglu, G., \& Buyukozturk, Ş. (2012). Multivariate SPSS and LISREL applications for social sciences (in Turkish). Ankara: Pegem Publishing.

Coulthard, N., \& Ogden, J. (2018). The impact of posting selfies and gaining feedback ("likes") on the psychological wellbeing of 16-25 year olds: An experimental study. Cyberpsychology: Journal of Psychosocial Research on Cyberspace, 12(2). doi:10.5817/cp2018-2-4.

Craker, N., \& March, E. (2016). The dark side of Facebook ${ }^{\circledR}$ : The Dark Tetrad, negative social potency, and trolling behaviours. Personality and Individual Differences, 102, 79-84. doi:10.1016/j.paid.2016.06.043.

Edwards, F. (2017). An investigation of attention-seeking behavior through social media post framing. Athens Journal of Mass Media and Communications, 3(1), 25-44. 
Ellison, N. B., Steinfield, C., \& Lampe, C. (2007). The benefits of Facebook "friends:” Social capital and college students' use of online social network sites. Journal of ComputerMediated Communication, 12(4), 1143-1168. doi:10.1111/j.1083-6101.2007.00367.x.

Ellison, N., Heino, R., \& Gibbs, J. (2006). Managing impressions online: Self-presentation processes in the online dating environment. Journal of Computer-Mediated Communication, 11(2), 415-441. doi:10.1111/j.1083-6101.2006.00020.x.

Fardouly, J., Pinkus, R. T., \& Vartanian, L. R. (2017). The impact of appearance comparisons made through social media, traditional media, and in person in women's everyday lives. Body Image, 20, 31-39. doi:10.1016/j.bodyim.2016.11.002.

Gosling, S. D., Augustine, A. A., Vazire, S., Holtzman, N., \& Gaddis, S. (2011). Manifestations of personality in online social networks: Self-reported Facebookrelated behaviors and observable profile information. Cyberpsychology, Behavior, and Social Networking, 14(9), 483-488. doi:10.1089/cyber.2010.0087.

Guohua, Z., Yanying, D., Li, L., \& Xianliang, Z. (2012). The development and application of the scale of adolescents' online self-presentation. Procedia Engineering, 29, 16511655. doi:10.1016/j.proeng.2012.01.189.

Hawk, S. T., van den Eijnden, R. J., van Lissa, C. J., \& ter Bogt, T. F. (2019). Narcissistic adolescents' attention-seeking following social rejection: Links with social media disclosure, problematic social media use, and smartphone stress. Computers in Human Behavior, 92, 65-75. doi:10.1016/j.chb.2018.10.032.

Hogue, J. V., \& Mills, J. S. (2019). The effects of active social media engagement with peers on body image in young women. Body Image, 28, 1-5. doi:10.1016/j.bodyim.2018.11.002.

Hongladarom, S. (2011). Personal identity and the self in the online and offline world. Minds and Machines, 21(4), 533-548. doi:10.1007/s11023-011-9255-x. 
Hood, M., Creed, P. A., \& Mills, B. J. (2018). Loneliness and online friendships in emerging adults. Personality and Individual Differences, 133, 96-102. doi:10.1016/j.paid.2017.03.045.

Hughes, C. M., Griffin, B. J., \& Worthington, E. L. (2017). A measure of social behavior in team-based, multiplayer online games: The Sociality in Multiplayer Online Games (SMOG) scale. Computers in Human Behavior, 69, 386-395. doi:10.1016/j.chb.2016.12.043.

Jin, S.-A. A. (2012). The virtual malleable self and the virtual identity discrepancy model: Investigative frameworks for virtual possible selves and others in avatar-based identity construction and social interaction. Computers in Human Behavior, 28(6), 2160-2168. doi:10.1016/j.chb.2012.06.022.

Kaşıkara, G., \& Doğan, U. (2017). Desire for Being Liked Scale: Validity and reliability study. MSKU Journal of Education, 4(2), 51-60.

Khalis, A., \& Mikami, A. Y. (2018). Talking face-to-Facebook: Associations between online social interactions and offline relationships. Computers in Human Behavior, 89, 88-97. doi:10.1016/j.chb.2018.07.033.

Kim, J. W., \& Chock, T. M. (2017). Personality traits and psychological motivations predicting selfie posting behaviors on social networking sites. Telematics and Informatics, 34(5), 560-571. doi:10.1016/j.tele.2016.11.006.

Kline, P. (1994). An easy guide to factor analysis. Oxford: Routledge.

Köse, S., Sayar, K., Ak, I., Aydin, N., Kalelioğlu, Ü., Kirpinar, I., ... \& Cloninger, C. R. (2004). Turkish version of the TCI: Reliability, validity, and factorial structure. Bulletin of Clinical Psychopharmacology, 14(3), 107-131. 
Kowalski, R. M., Giumetti, G. W., Schroeder, A. N., \& Lattanner, M. R. (2014). Bullying in the digital age: A critical review and meta-analysis of cyberbullying research among youth. Psychological Bulletin, 140(4), 1073-1137. doi:10.1037/a0035618.

Lau, W. W. F., \& Yuen, A. H. K., (2013). Adolescents' risky online behaviours: The influence of gender, religion, and parenting style. Computers in Human Behavior, 29(6), 2690-2696. doi:10.1016/j.chb.2013.07.005.

Luppicini, R., \& Haghi, A. K. (2012). Education for a digital world: present realities and future possibilities. New York: CRC Press.

Manago, A. M., Graham, M. B., Greenfield, P. M., \& Salimkhan, G. (2008). Self-presentation and gender on MySpace. Journal of Applied Developmental Psychology, 29(6), 446458. doi:10.1016/j.appdev.2008.07.001.

Mills, J. S., Musto, S., Williams, L., \& Tiggemann, M. (2018). "Selfie” harm: Effects on mood and body image in young women. Body Image, 27, 86-92. doi:10.1016/j.bodyim.2018.08.007.

Morrow, J. R., Mood, D., Disch, J., \& Kang, M. (2015). Measurement and evaluation in human performance (4th ed.). Champaign, IL: Human Kinetics.

Orosz, G., Tóth-Király, I., \& Bőthe, B. (2016). Four facets of Facebook intensity- The development of the Multidimensional Facebook Intensity Scale. Personality and Individual Differences, 100, 95-104. doi:10.1016/j.paid.2015.11.038.

Pal, A., Chua, A. Y. K., \& Hoe-Lian Goh, D. (2019). Debunking rumors on social media: The use of denials. Computers in Human Behavior, 96, 110-122. doi:10.1016/j.chb.2019.02.022.

Panek, E. T., Nardis, Y., \& Konrath, S. (2013). Mirror or Megaphone?: How relationships between narcissism and social networking site use differ on Facebook and Twitter. Computers in Human Behavior, 29(5), 2004-2012. doi:10.1016/j.chb.2013.04.012. 
Pang, H. (2018). Microblogging, friendship maintenance, and life satisfaction among university students: The mediatory role of online self-disclosure. Telematics and Informatics, 35(8), 2232-2241. doi:10.1016/j.tele.2018.08.009.

Panger, G. T. (2017). Emotion in social media. (Doctoral dissertation). University of California, Berkeley.

Qiu, L., Lin, H., Leung, A. K., \& Tov, W. (2012). Putting Their Best Foot Forward: Emotional Disclosure on Facebook. Cyberpsychology, Behavior, and Social Networking, 15(10), 569-572. doi:10.1089/cyber.2012.0200.

Qiu, L., Lu, J., Yang, S., Qu, W., \& Zhu, T. (2015). What does your selfie say about you? Computers in Human Behavior, 52, 443-449. doi:10.1016/j.chb.2015.06.032.

Ramsey, L. R., \& Horan, A. L. (2018). Picture this: Women's self-sexualization in photos on social media. Personality and Individual Differences, 133, 85-90. doi:10.1016/j.paid.2017.06.022.

Rosenthal-von der Pütten, A. M., Hastall, M. R., Köcher, S., Meske, C., Heinrich, T., Labrenz, F., \& Ocklenburg, S. (2019). "Likes" as social rewards: Their role in online social comparison and decisions to like other People's selfies. Computers in Human Behavior, 92, 76-86. doi: 10.1016/j.chb.2018.10.017.

Şahin, N. H., \& Şahin, N. (1992). How dysfunctional are the dysfunctional attitudes in another culture? British Journal of Medical Psychology, 65(1), 17-26. doi:10.1111/j.2044-8341.1992.tb01680.x.

Savci, M., \& Aysan, F. (2019). A hypothetical model proposal for social connectedness in adolescents. Turkish Psychological Counseling and Guidance Journal, 9(54), 589621.

Savci, M., Turan, M. E., Griffiths, M. D., \& Ercengiz, M. (2019). histrionic personality, narcissistic personality, and problematic social media use: Testing of a new 
hypothetical model. International Journal of Mental Health and Addiction. Epub ahead of print. doi:10.1007/s11469-019-00139-5.

Schouten, A. P., Valkenburg, P. M., \& Peter, J. (2007). Precursors and underlying processes of adolescents' online self-disclosure: Developing and testing an "Internet-attributeperception” model. Media Psychology, 10(2), 292-315. doi:10.1080/15213260701375686.

Sest, N., \& March, E. (2017). Constructing the cyber-troll: Psychopathy, sadism, and empathy. Personality and Individual Differences, 119, 69-72. doi:10.1016/j.paid.2017.06.038.

Sherman, L. E., Hernandez, L. M., Greenfield, P. M., \& Dapretto, M. (2018). What the brain "Likes": Neural correlates of providing feedback on social media. Social Cognitive and Affective Neuroscience, 13(7), 699-707. doi:10.1093/scan/nsy051.

Singh, S., Farley, S. D., \& Donahue, J. J. (2018). Grandiosity on display: Social media behaviors and dimensions of narcissism. Personality and Individual Differences, 134, 308-313. doi:10.1016/j.paid.2018.06.039.

Sorokowski, P., Sorokowska, A., Frackowiak, T., Karwowski, M., Rusicka, I., \& Oleszkiewicz, A. (2016). Sex differences in online selfie posting behaviors predict histrionic personality scores among men but not women. Computers in Human Behavior, 59, 368-373. doi:10.1016/j.chb.2016.02.033.

Stieglitz, S., \& Dang-Xuan, L. (2013). Emotions and information diffusion in social mediasentiment of microblogs and sharing behavior. Journal of Management Information Systems, 29(4), 217-248.

Sutcliffe, A. G., Binder, J. F., \& Dunbar, R. I. M. (2018). Activity in social media and intimacy in social relationships. Computers in Human Behavior, 85, 227-235. doi:10.1016/j.chb.2018.03.050. 
Tabachnick, B. G., \& Fidell, L. S. (2013). Using multivariate statistics (sixth edition). Harlow, England: Pearson Education.

Taymur, İ., Türkçapar, M. H., Örsel, S., Sargın, E., \& Akkoyunlu, S. (2011). Validity and reliability of the Turkish version of the Personality Belief Questionnaire-Short Form (PBQ-STF) in the university students. Turkish Journal of Clinical Psychiatry, 14(4), 199-209.

Tiggemann, M., \& Barbato, I. (2018). "You look great!”: The effect of viewing appearancerelated Instagram comments on women's body image. Body Image, 27, 61-66. doi:10.1016/j.bodyim.2018.08.009.

Van Geel, M., Goemans, A., Toprak, F., \& Vedder, P. (2017). Which personality traits are related to traditional bullying and cyberbullying? A study with the Big Five, Dark Triad and sadism. Personality and Individual Differences, 106, 231-235. doi:10.1016/j.paid.2016.10.063.

Van Oosten, J. M. F., \& Vandenbosch, L. (2017). Sexy online self-presentation on social network sites and the willingness to engage in sexting: A comparison of gender and age. Journal of Adolescence, 54, 42-50. doi:10.1016/j.adolescence.2016.11.006.

van Oosten, J. M., de Vries, D. A., \& Peter, J. (2018). The importance of adolescents' sexually outgoing self-concept: Differential roles of self-and other-generated sexy selfpresentations in social media. Cyberpsychology, Behavior, and Social Networking, 21(1), 5-10. doi:10.1089/cyber.2016.0671.

Wang, S. S. (2013). "I share, therefore I am": Personality traits, life satisfaction, and Facebook check-ins. Cyberpsychology, Behavior, and Social Networking, 16(12), 870877. doi:10.1089/cyber.2012.0395. 
Weeks, B. E., Ardèvol-Abreu, A., \& Gil de Zúñiga, H. (2015). Online influence? Social media use, opinion leadership, and political persuasion. International Journal of Public Opinion Research, Volume 29(2), 214-239, doi:10.1093/ijpor/edv050.

Wuang, Y.-P., Su, C.-Y., \& Huang, M.-H. (2011). Psychometric comparisons of three measures for assessing motor functions in preschoolers with intellectual disabilities. Journal of Intellectual Disability Research, 56(6), 567-578. doi:10.1111/j.13652788.2011.01491.x.

Wyrwich, K. W., Nienaber, N. A., Tierney, W. M., \& Wolinsky, F. D. (1999). Linking clinical relevance and statistical significance in evaluating intra-individual changes in health-related quality of life. Medical Care, 37(5), 469-478. doi:10.1097/00005650199905000-00006.

Yang, C., \& Bradford-Brown, B. (2015). Online self-presentation on Facebook and self development during the college transition. Journal of Youth and Adolescence, 45(2), 402-416. doi:10.1007/s10964-015-0385-y. 